\title{
NOTES ON SOME ANIMAL PARASITES IN BRITISH GUIANA.
}

\author{
By G. E. Bodkin, B.A., Dip. Agric. (Cantab.), F.Z.S., F.E.S., \\ Government Economic Biologist, British Guiana; \\ and \\ L. D. Cleare, Jnr., F.E.S., \\ Biological Division, Dept. Sc. \& Agric., British Guiana.
}

\section{(MAP III.)}

British Guiana lies between the latitudes $0 \cdot 41^{\prime} \mathrm{N}$. (source of the Essequebo River) and $8^{\circ} 33^{\prime} 22^{\prime \prime}$ N. (Punta Playa), has a depth from north to south of about 500 miles, a seaboard of about 270 miles trending in a south-easterly direction, and occupies in the north-east of South America an area approximately equal in extent to Great Britain. It is bounded on the north by the Atlantic Ocean, on the east by Surinam or Dutch Guiana, on the south and south-west by Brazil, and on the west by Venezuela.

The Colony may be divided broadly into three belts.* The northern one consists of a low-lying flat and swampy belt of marine alluvium-the coastal region. This rises gradually from the seaboard and extends inland for a distance varying from 5 to 49 miles. It is succeeded by a broader and slightly elevated tract of country of sandy and clayey soils. This belt is generally undulating, and is traversed in places by sand-dunes rising from 50 to $180 \mathrm{ft}$. above sea-level. The more elevated portion of the Colony lies to the southward of the above-mentioned regions. It rises gradually to the south-west, between the river valleys, which are in many parts swampy, and contains three principal mountain ranges, several irregularly distributed smaller ranges, and in the southern and eastern parts numerous isolated hills and mountains. The eastern portion is almost entirely forest-clad, but on the southwestern side there is an extensive area of flat grass-clad savannah land elevated about 300 feet above sea-level.

British Guiana has at times been described as an unhealthy country. This is an undeserved calumny, as is clearly shown by the statistics of mortality of European races other than Portuguese. For those who lead regular lives and do not expose themselves to unnecessary risks the climate is decidedly a healthy one. The coastlands are swept throughout the year by the north-eastern trade winds, which add greatly to the comfort, vigour and health of those resident thereon. The mean annual rainfall near the coast is about 94 inches, and further inland about 105 inches. The average mean shade temperature at or near the coast-lands for the past twenty-two' years is $80.0 \mathrm{~F}$. The average mean maximum is $85 \cdot 1 \mathrm{~F}$., and the average mean minimum $74.9 \mathrm{~F}$. The greatest annual range is about $19 \mathrm{~F}$.

\footnotetext{
*These notes on the geography and climate of the Colony have been reprinted from an article on the field and forest resources of British Guiana in Bull. Imperial Institute, xiii, No. 2, April-June, 1915, p. 203.
} 
During past years entomology, economic or otherwise, has received but slight attention from residents in British Guiana. A number of scattered references to the subject appear in the leading entomological publications of several countries, but in the main these are the results of visits or expeditions to the Colony of professional collectors, and only occasionally the work of local amateurs.

With a very few exceptions all the species and observations recorded in this article are the outcome of our own work during the last two-and-a-half years, which has been carried out as opportunities occurred. No paid local collectors have been employed, as we have found that as soon as the financial element is introduced they rapidly become untrustworthy and little or no faith can be placed in their observations.

We are indebted to Mr. A. A. Abraham, Agricultural Instructor in charge of the Government Experiment Station in the North West District, who has on several occasions sent small collections of Tabanidae and Mallophaga from this part of the Colony together with careful observations regarding their habits. Also to $\mathrm{Mr}$. S. $\mathrm{H}$. Bayley, the Superintendent of the Onderneeming Industrial School, for several species of parasitic worms from the livestock kept on the farm.

Mr. M. A. de Freitas, of the British Guiana Museum, has kindly assisted in procuring several species of lice from birds collected by himself for the preservation of their skins in the Museum collection. Material has been obtained from all the important agricultural areas and from some of the more remote inland districts.

Identifications are in every way reliable for they have been made through the co-operation of the Imperial Bureau of Entomology by specialists either in the British Museum or elsewhere.

\section{Methods of Collecting.}

The collecting of parasites is not always an easy matter. Opportunities for collecting have a habit of occurring at most inconvenient times, which necessitates: the constant carrying of a suitable equipment. Fortunately this need not be cumbersome and the following short notes on methods of collecting and the equipment used, which we have found to meet all requirements in actual practice, may prove of interest. to other entomologists engaged in similar work in the tropics.

For capturing various species of lice a pair of forceps about $10 \mathrm{cms}$. in length with fine rounded points having a perfectly smooth gripping surface will be foind useful. The part which in use is held between the fingers should have a milled surface so as. to afford a firm hold.

A flat tin box of a convenient pocket size with partitions to hold about a dozen medium-sized tubes containing alcohol and stoppered with well-fitting corks is also necessary. Paper and pencil should always be carried, as it is most important that. data concerning the host, date, locality, and other particulars of interest should be accurately recorded at the time of actual collection. The piece of paper containing these notes should be enclosed in the tube along with the specimens.

For capturing Tabanidae and other bloodsucking Diptera a net is of course necessary, but an individual possessed of a quick eye and a steady hand can accomplish much without it. 
TABANIDAE, especially when feeding, can often easily be captured by carefully placing over them a killing tube ; as soon as the fly finds itself imprisoned it will fly up into the tube and the cork may then rapidly be inserted, or else the tube may be held over the insect in situ while the cyanide does its work; with a restive animal however this is not always possible.

A convenient-sized tube for this work is one about $8 \mathrm{cms}$. in length and $3 \mathrm{cms}$. in diameter and of good quality thick glass. The cork should fit well, but not too tightly, or trouble will be experienced in its withdrawal; it should be well waxed externally.

Small pieces of cyanide mixed with a somewhat larger quantity of boracic acid powder are placed in the bottom of the tube and rammed well down; a thin layer of cotton wool follows also well rammed down, and finally about 3 or 4 disks of thick blotting paper, cut out slightly larger than the diameter of the tube so that they fit tightly when pressed down and thus prevent the entire mass from shifting. The boracic powder prevents the cyanide from deliquescing and also seems slightly to. stimulate its action. The whole mass should not occupy more than about $3 \mathrm{cms}$. of the length of the tube.

A further advantage of this method lies in the fact that when the cyanide becomes exhausted it can easily be removed and the tube recharged; anyone who has used the plaster of Paris and cyanide method of charging killing bottles is familiar with the difficulties and inconveniences of recharging, especially in the damp atmosphere of the tropics, which hastens the deliquescence of the cyanide.

Ticks are easily collected by means of the forceps, though care should be taken in removing them, so as not to leave the mouth-parts embedded in the cuticle of the host.

Lice are often hard to find, especially on birds, but experience will in time indicate the most likely parts of the body on which to search.

When examining poultry and other kinds of birds better results will be obtained if a person is employed to hold the bird firmly in a convenient position while a careful examination is being made.

A pair of small but sharp scissors often prove useful for the entire removal of a feather or feathers infested with lice. The specimens can afterwards be removed in the laboratory with a certainty and exactness seldom possible under field conditions.

\section{Parasitic Worms.}

Our investigations in connection with parasitic worms, carried out principally among domestic animals, have revealed a highly interesting field of almost unlimited scope. A curious feature is the comparative rarity of tapeworms among the ordinary creole dogs. We have never encountered them during our post mortem examinations and only very rarely have the cast mature segments been observed.

The determinations have in all cases been made by Mr. H. A. Baylis, Department of Zoology, British Museum. Unfortunately, in some cases the specimens were not sufficiently well preserved to allow of a certain identification. A number of other worms have been collected from various hosts, but owing to the present European conditions we have been unable to get them identified. 


\title{
Class NEMATODA.
}

\author{
Family Filaridae.
}

Filaria cervina, Duj. A single specimen of this parasite was obtained from the abdominal cavity of a cow at the Georgetown Abattoir. It does not appear to be a common species.

Filaria physalura, Bremser. Some splendid specimens of this large worm were taken from the Collared Kingfisher (Ceryle torquata), a large bird of common occurrence. Several specimens were taken from the connective tissue about the neck, while the heart was enveloped with a large specimen which had coiled itself tightly around this organ. We are indebted for this specimen to Mr. M. A. de Freitas, who secured it while on a collecting expedition in the upper reaches of the Demerara River.

Filaria immitis, Leidy. It would probably be a difficult matter to find a creole dog over two years in age which does not harbour this parasite. Dogs about two years old generally possess at least one adult worm in the heart itself or in the pulmonary artery. In old dogs a thick tangled mass of the worms is often found in these organs, which would appear to choke them completely. However, the presence of this parasite seems to have but little effect on the general well-being of the dog. Imported dogs seem to thrive and are not rapidly killed by this worm as has been reported from China. The mosquito, Culex fatigans, Wied., is the probable vector of the disease.

Filaria sp. Large numbers of a filarial worm were taken from the body cavity of the White-breasted Swallow (Tachycineta albiventris). Poor preservation of the specimens rendered an exact determination impossible.

\section{Family Ascaridae.}

Ascaris megalocephala, Cloquet. One specimen of this large worm was obtained from a horse after the administration of a purgative.

\section{Family Strongyurdae.}

Ankylostoma sp. A common species, resembling $A$. ceylanicum, Loos, in the intestine of most dogs. As many as 15 of these worms have been taken from one dog.

Physaloptera? praeputialis, Linst. An exceedingly common parasite in the stomach of most cats. From 4 to 12 of these worms are usually found firmly attached to the stomach wall. Lutz has recorded the occurrence of this parasite in Brazil in the same host.

\section{Class PLATYHELMINTHES.}

Dicorcelium sp., near D. lanceatum, Stiles \& Hassall. This parasite seems to be extremely prevalent among cats in the colony. At times the liver will be found to be very heavily infested, while in other cases only a few flukes will be found.

\section{Class CESTODA.}

Moniezia expansa, Rud. This species was taken from a pig at the Georgetown Abattoir. It is not normally a parasite of the pig, but it is possible that in some manner or other the worm as excreted from its original host may have been consumed by this animal, as pigs are notorious eaters of all kinds of refuse and filth. 


\section{Class ACANTHOCEPHALA.}

Echinorynchus gigas, Goeze. This appears to be a common inhabitant of the small intestine of pigs in British Guiana; numerous specimens have, on various occasions, been obtained from pigs slaughtered at the Georgetown Abattoir.

\section{Class ARACHNIDA.}

\section{Order ACARINA.}

\section{Family IxodidaE.}

In British Guiana all kinds of live-stock are attacked by various species of ticks, which are in many cases directly responsible for a very considerable annual financial loss. Preventive measures, such as dipping, are quite unheard of and the presence of these pests is universally regarded with the utmost indifference.

Argas persicus, Wald. This tick is a common inhabitant of fowl-houses throughout the Colony, and the larvae are to be found on most varieties of poultry. The larval stage of this tick is known locally as "Nimbles."

Rhipicephalus sanguineus, Latr. One of the commonest external parasite of dogs. All stages of development may be found on this animal. Between the digits and within the ears are favourite points of attachment.

Margaropus annulatus var. australis, Fuller. Flourishes on all kinds of cattle. Steers that have been in the pastures for a few months soon become heavily infested and thereby loose weight and condition. Instances have been observed where several ticks have attached themselves to the eyelids and engorging there caused intense irritation. The death of a calf through tick infestation is not uncommon. The institution of properly constructed dipping or spraying contrivances would handsomely repay the initial outlay. This tick has a number of other hosts, including the common toad or "Crapaud" (Bufo marinus).

Amblyomma cajennense, F. Locally known as the Balata Tick. In certain districts of the coast-lands, usually near the rivers or creeks and also within the forest area, this tick is commonly met with as a parasite of man. In these infested areas after traversing but a few miles as many as a dozen of these ticks will often be found attached to different parts of the body. Unless carefully removed an irritating spot is left which will prove troublesome for some months.

Amblyomma humerale, Koch. This tick has been twice taken from turtles and on both occasions some distance inland. The points of attachment are the softer and unarmoured parts of the head and neck, especially about the eyes and mouth. Some 24 specimens were taken from a single turtle.

Amblyomma dissimile, Koch. This species is a common parasite of cold-blooded animals, such as toads, lizards, and many varieties of snakes. It is widely distributed. The ordinary toad (Bufo marinus) invariably bears several specimens attached to the head immediately between the eyes and occasionally on the back. These ticks are especially numerous after the heavy rainy seasons in January and usually again in May. A single engorged specimen fully half-inch in diameter was on one occasion taken from a Salampenta (Turpinambis nigropunctatus). We have also taken this species from the Iguana (Iguana tuberculata). 


\section{Class HEXAPODA.}

\section{Order DIPTERA. \\ Family Tabanidat.}

Within the coastal region the TABANIDAE are of common occurrence, though they are chiefly composed of large numbers of a few common species. Within the forest areas, however, these coast-land species seldom appear and their place is taken by numerous other species, some of which are comparatively rare. According to information received, the savannah lands near the Brazilian border are particularly rich in TABanidaE, but up to the present no opportunity has occurred for collecting or making definite observations within this area.

The common species of TABANIDAE that attack live-stock on the coast-lands belong to the genus Tabanus-T. trilineatus, Latr., $T$. senior, Wlk., and $T$. semisordidus, Wlk. ; of these $T$. trilineatus is possibly the commonest and most widely distributed.
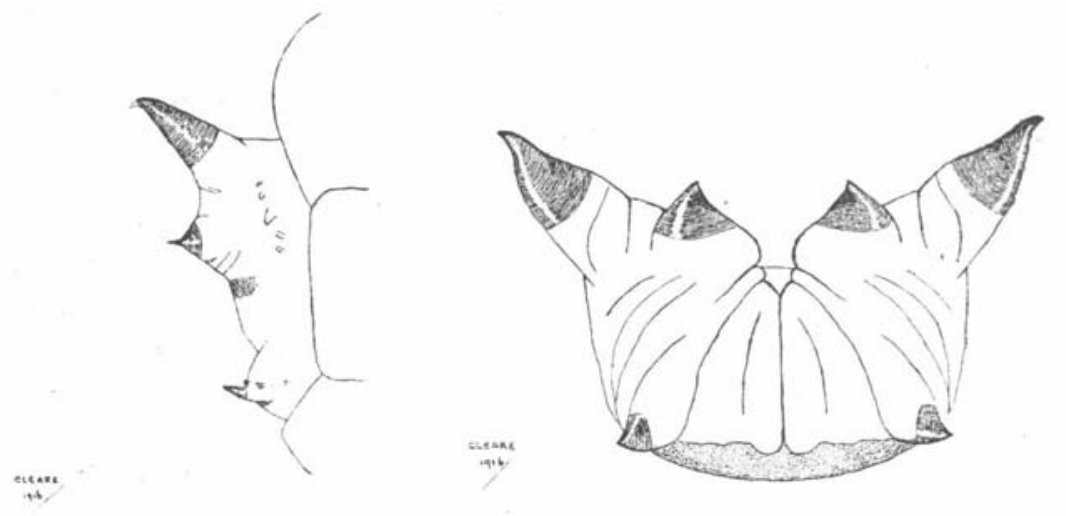

Fig. 1. Pupal aster of Tabanus desertus, Walk., $\subseteq$ : lateral and posterior aspects.

The numerous muddy trenches and ditches that are necessary for drainage purposes all over the coastal area, and more especially in the cultivated portions such as the sugar estates, provide very suitable breeding places for these flies, but very little is known of their life-histories; a wide and fascinating field for research is thus presented.

The egg-masses of $T$. semisordidus, Wlk., have been observed to be deposited on the leaves of aquatic grasses and in some instances on the leaves of young rice plants. They are laid in a neat little bundle consisting of some 20 or more cigar-shaped shining black eggs adhering to one another and to the leaf surface.

The larval and pupal stages of $T$. desertus, Wlk., have been observed by us. Numbers of the larvae were found in a damp accumulation of sweepings situated at the end of a drain leading from a large cattle pen. Several of these larvae were secured and kept in the laboratory under frequent observation. Although supplied with a quantity of suitable food the largest larva eventually consumed its companions and pupated. After 16 days a female Tabanus desertus emerged. 
A recent outbreak of Mal de Caderas (Trypanosoma equinum) amongst the sugar plantation mules was in all probability propagated by biting flies, and most of the common species of TABanIDaE and other biting flies, such as the well-known Stomoxys calcitrans, L., were observed to feed freely on mules afflicted by this deadly equine disease.

The principal enemies of TABANIDAE are several species of the large predaceous wasps belonging to the Bembecinae. These, owing to their characteristic yellow and black coloration and fierce habits, have received the peculiar Creole name of " Cowfly tiger." On the coast-lands the commonest species are Monedula signata, Latr., M. punctata, Lep., and M. surinamensis, Dahlb., while in the forest area the formidable M. pantherina, Handl., is frequently met with. Bembidula discisa, Tasch., and Bembidula variegata, $\mathrm{Ol}$., are also encountered in this region.

Wherever Tabanidae occur, large numbers of these wasps will be observed to be active, especially round cattle and mules when in the pastures. Despite the loud buzzing flight and active darting movements of their enemies, the TABANIDAE seldom display any concern at their presence, though they take good care to choose those portions of their host least exposed to the manouvres of the wasps. They are always more numerous on sandy soils, which provide greater facilities for their nesting habits.

The Asilid fly, Mallophora calidus, F., is also an occasional enemy of TABanidae in the coastal area; owing to its size however it is capable of attacking only the smaller species.

Dicranomyia cervus, Wied. A not uncommon species in some of the interior districts. Readily attacks man.

Chrysops tristis, F. This is a common species and is widely distributed throughout the coastal region, it is occasionally met with in the forest area. It has a very distinct tendency to attack man, and owing to its stealthy method of approach, the first indication of its presence is usually the sharp pain caused by the insertion of its proboscis, generally in some exposed part of the back of the neck. It is a shadeloving species and is most active during the early morning hours and at eventide.

Chrysops costata, F. Only met with in certain districts where the soil is of a sandy nature and in the proximity of large areas of fresh water. It has the same tendency to attack human beings as $C$. tristis and has much the same method of approach.

Chrysops fulviceps, Wlk. Apparently only encountered in the forest area, and nothing is known of its habits.

Bolbodimyia bicolor, Big. Apparently an uncommon species. One specimen was taken while attacking man in the North West District.

Lepidoselaga crassipes, F. One specimen of this handsome fly has been taken on the coast-lands while attacking man.

Diachlorus scutellatus, Macq. (fig. 2), D. podagricus, F., D. curvipes, F. These three species at certain times of the year are extraordinarily abundant. and during these periods they become a most obnoxious pest, owing to their persistent and bloodthirsty attacks on human beings. Their habitat is in the forest areas, especially near the rivers in the North-West District. 
Dichelacera damicornis, F. This fly has a distinct partiality for the blood of human beings and has much the same method of attack as Chrysops. It is found only within the forest area.

Dichelacera testacea, Macq. Within the forest area this is a common species and will readily attack man. Its bite produces considerable local irritation and swelling.

Tabanus senior, Wlk. This fly is much like T. semisordidus, Wlk., in appearance and habits, and in the field they may easily be mistaken for one another. T. senior is commonly found about stock of all kinds in the pastures throughout the year and is a particularly voracious and bloodthirsty species. It is capable of inflicting a severe wound with its large and lancet-like proboscis, and instances have been observed where the repeated wounds caused by this species have caused the legs of mules and cattle to bleed freely. It has a very rapid and noisy flight, but when once settled down and feeding it is easily captured and may even be picked off by hand. No instance has come under observation of its attacking human beings.

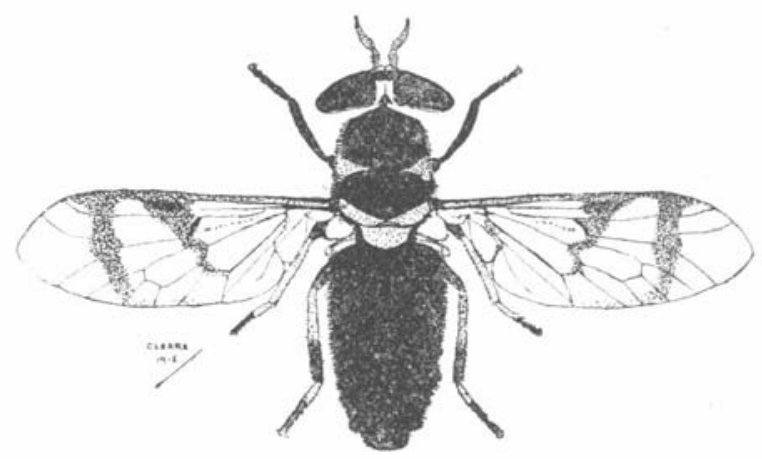

Fig. 2. Diachlorus scutellatus, Meq. $\&, \times 5$.

Tabanus semisordidus, Walk. Has the same habits as the previous species, the two frequently occurring together.

Tabanus impressus, Wied. In size this is slightly larger than the two previous species and has much the same appearance, but it is of rarer occurrence. It appears to be widely distributed, and on several occasions has been known to attack man.

Tabanus imponens, Wlk. Only one specimen of this fly has been captured and nothing is known of its habits or life-history.

Tabanus trilineatus, Latr. The common Tabanid of British Guiana, and it appears to be distributed over both the forest and coastal area. It is not so voracious as $T$. semisordidus and specimens are usually captured while resting on foliage. No instance has been observed of its attacking human beings. It frequently is attracted to artificial light.

Tabanus desertus, Wlk. (fig. 3). The feeding habits of this fly have never been observed, though numbers have been collected from time to time. It appears to be a peculiarly inert species and is attracted by artificial light. 
Tabanus caiennensis, F. This species is very occasionally met with on the coastlands while attacking stock. In some of the interior districts it is common and réadily attacks man.

Tabanus leucaspis, Wied. Of rare occurrence within the forest area, where it has been observed to attack man.

Tabanus ochroleucus, Mg. This peculiar Tabanid is frequently taken in human habitations, being attracted there by artificial light. It has been known to attack man.

Tabanus trifascia, Wlk. Closely allied to $T$. trilineatus and with very similar habits.

Tabanus oculus, Wlk. One specimen of this insect has been taken in the interior districts while attacking man.

\section{Family Anthomyidae.}

Mydaea pici, Macq. The larvae of this fly are subcutaneous parasites of birds, such as the Kiskadee (Pitangus sulphuratus) and the Twa-Twa Slave (Aryzoborus torridus) on the coast-lands.

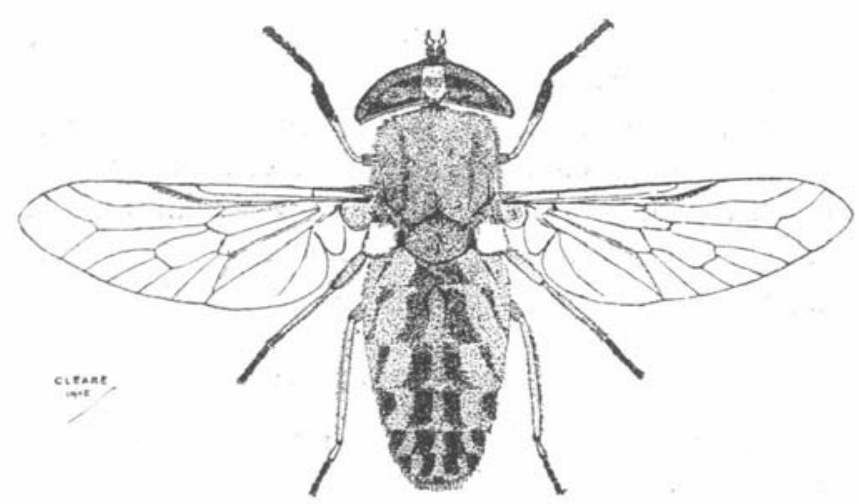

Fig. 3. Tabanus desertus, Walk., 우 $\times 4$.

\section{Family Muscidae.}

Stomoxys calcitrans, L. In all parts of the coastal area and in many of the inhabited areas of the inland regions this fly is of common occurrence. About stables in Georgetown, and particularly about the mule stables and compounds on the sugar estates, numbers of these flies are continually active, more especially in the early morning and evening hours. In the absence of other food supplies it will readily attack human beings and often proves most irritating. No decided increase in its numbers has been observed at any special season of the year.

\section{Family Hippoboscidae.}

A number of these flies are known to infest different kinds of birds and somemammals, but their activity, and the manner in which they quickly leave their host at its death, renders their capture extremely difficult.

Lynchia maura, Bigot. Frequently found on domestic pigeons. 
G. E. BODKIN AND L. D. CLEARE, JNR.

\section{Order SIPHONAPTERA.}

\section{Family SARCopsyllidat.}

Dermatophilus penetrans, L. This well-known species is widely distributed over the Colony. They are known locally as Jiggers or Chigoes.

Family Pulicidae.

Ctenocephalus felis, Bouché. Probably the commonest species on the coast-lands. It is the common flea of domestic cats and dogs and occasionally attacks man.

Order RHYNCHOTA.

\section{Family Crmicidae.}

Cimex hemiptera, F. (rotundatus, Sign.). This species is the common bed-bug of British Guiana.

\section{Order ANOPLURA.}

Family Pediculidae.

Pediculus capitis, de Geer. A parasite of Negros, East Indians, etc., in the Colony. The colour varies slightly according to the host.

Pediculus humanus, L. This species is not nearly so frequently met with as the former. It has been collected solely from East Indians. They are much lighter in colour than $P$. capitis, being a whitish grey. They are known locally as "white lice " and are said to be most voracious in their habits.

Phthirius pubis, L. Is found as a parasite of all the different races inhabiting British Guiana.

\section{Family Haematopinidae.}

Haematopinus eurysternus, Nitzsch. Collected from cattle on the coast-lands. It is the common cattle louse.

Haematopinus tuberculatus, Nitzsch. This species was collected from imported Indian buffaloes, which apparently are the only hosts in British Guiana.

Haematopinus suis, L. Very common on pigs. It was collected several times on these animals at the Georgetown Abattoir.

\section{Order $M A L L O P H A G A$.}

This order is well represented in British Guiana. From the economic standpoint the presence of ill-kept and overcrowded fowl-houses and pigeon-lofts and pens of a like character for sheep and goats accounts largely for the abundance of these parasites and for their wide distribution among domestic animals.

Some species of birds in the wild state appear to be heavily infested with lice, while others again are almost entirely exempt.

\section{Family Trichodectidae.}

Trichodectes pilosus, Gieb. On donkey (Equus asinus).

Trichodectes climax, N. On goat (Capra hircus).

Trichodectes sphaerocephalum, N. On sheep (Ovis aries). 
Family Philopteridae.

Philopterus breviformis, Kell. \& Kuw. From Progne chalybdea, the common swallow of the coast-lands in British Guiana.

Philopterus duplicatus, Piag. From Ceryle torquata, a common species of Kingfisher on the coast-lands.

Philopterus obscurus, Gieb. From Rostrhamus sociabilis, a common species of Snail-eating Buzzard, and also from a Peacock (Pavo cristatus) in the Botanic Gardens, Georgetown.

Degeeriella sp. From the White-breasted Harrier Eagle (Herpetotheres cachinnans) and Rostrhamus sociabilis.

Paragoniocotes abnormis, Kell. From a small undetermined species of coast-land parrot.

Family Goniodidae.

Goniocotes curtus, N. From Opisthocomus cristatus, the well-known Hoatzin or Canje Pheasant.

Goniocotes gigas, Taschb. (= abdominalis, P.). Parasite of chickens (Gallus domesticus) and turkeys (Meleagris domestica).

Goniocotes hologaster, N. From pigeons (Columba domestica) and guinea-fowls (Numida meleagris).

Goniodes dissimilis, N. From chickens and turkeys.

Goniodes compar, N. From pigeons.

Goniodes pavonis, L. From a Peacock (Pavo cristatus) in the Botanic Gardens, Georgetown.

Goniodes stylifer, N. From turkeys.

\section{Family Lipeuridae.}

Lipeurus assessor, Gieb. From Rostrhamus sociabilis and Cathartes perniger.

Lipeurus baculus, N. From pigeons.

Lipeurus leucopygus, N. From Blue Heron.

Lipeurus polytrapezius, N. From chickens.

Lipeurus squalidus, N. From Muscovy duck and Herpetotheres cachinnans.

Lipeurus variabilis, N. From chickens, guinea-fowl and turkey.

Lipeurus sp. From the Blue Gaulding (Florida coerulea).

Family Menoponidae.

Menacanthus sp. From Rostrhamus sociabilis.

Menacanthus sp. From Opisthocomus cristatus.

Menopon biseriatum, P. From turkey (Meleagris domestica).

Menopon pallidum, N. From Gallus domestica, Numida meleagris, and Meleagris domestica.

Menopon macropus, Gieb. From Crux alector.

Myrsidea rustica, N. From Progne chalybdea. 
Colpocephalum dissimile, Piag. From Rostrhamus sociabilis, and also from the Caraow (Aramus scolopaceus).

Colpocephalum sp., near importunum, N. From a Chow (Butorides striata) and Blue Heron.

Colpocephalum maculatum, Piag. From the Brown Caracara Hawk (Polyborus cheriway), Herpetotheres cachinnans, Rostrhamus sociabilis, and the Gory-headed Kiskadee or Tyrant Bird (Tyrannus melancholicus).

Colpocephalum phaeostomum, N. From Pavo cristatus in the Botanic Gardens, Georgetown.

Colpocephalum sp. From Pavo cristatus.

Colpocephalum, N. From Columba domestica.

Family Physostomidae.

Physostomum angulatum, Kell. From Tyrannus melancholicus.

Physostomum sp. From Polyborus cheriway.

Family Laemobothriddae.

Laemobothrium opisthocomi, Cummings. From Hoatzin (Opisthocomus crislatus).

Laemobothrium sp. From Caraow (Aramus scolopaceus). These birds are always heavily infested with this species.

\section{Family GyropidaE.}

Gyropus ovalis, N. From guineapigs (Cavia porcellus).

Gliricola gracilis, N. From guineapigs. 


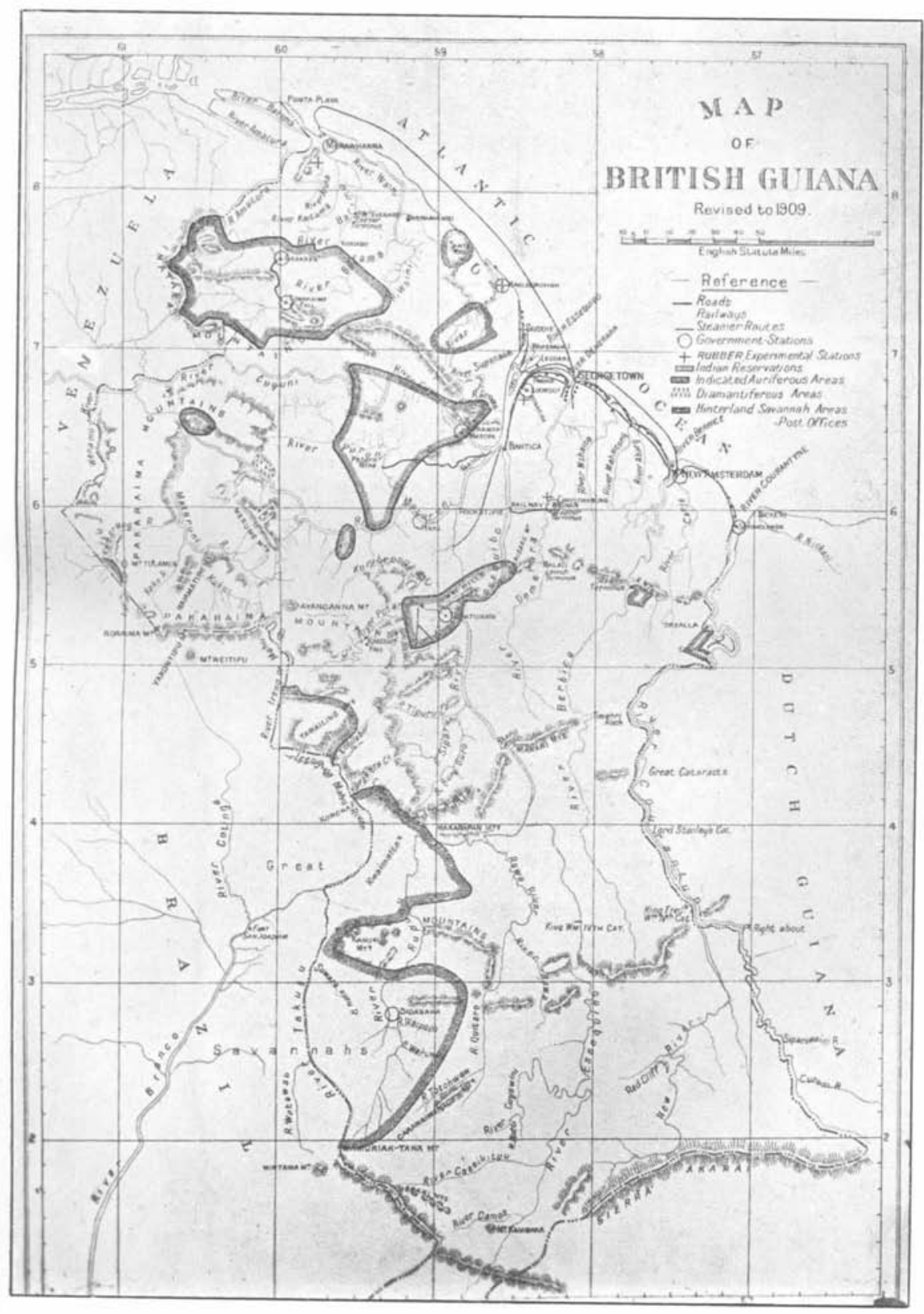

